\title{
Developing Kvisoft Flipbook Maker-Based Physics E-Module to Build on Critical Thinking Skills of Senior High School Students
}

\author{
Silvia Anggri Wijaya ${ }^{1, *}$ Jumadi $^{2}$ \\ ${ }^{1}$ Master of Physics Education, Faculty of Mathematics and Natural Science, Universitas Negeri Yogyakarta, \\ Indonesia \\ ${ }^{2}$ Department of Natural Science Education, Faculty of Mathematics and Natural Science, Universitas Negeri \\ Yogyakarta, Indonesia \\ *Corresponding author. Email: silviaanggri.2019@student.uny.ac.id
}

\begin{abstract}
This study aimed to develop e-module physics based Kvisoft Flipbook Maker (KFM) on the materials of harmonic motion in spring vibration material as a supporting learning material for the tenth-grade students of Senior High School. The study adapted the 4D development models (Define, Design, Develop, and Disseminate) in which the define stage was to describe problems in learning, the design stage was to produce initial products and research instruments, the develop stage was to obtain product and instrument feasibility, and the disseminate stage was for the widespread deployment of KFM-based Physics e-modules. The study subjects numbered 34 students in the tenth grade of Mathematics and Science (MIPA) 1 of Senior High State School (SMAN) of 1 PAKEM, samples were taken using purposive sampling. The research instruments employed were preliminary study questionnaires, material expert validation survey form, media expert validation survey form, and critical thinking skills tests. The data collection methods applied in this paper were validation, observation, pre-test, post-tests, and study of documentation. Data analyzing used was sign test. The results of the paper showed that 1) KFM-based Physics emodules developed fall into the valid category and are worth using. 2) Students' critical thinking skills during learning activities had improved significantly.
\end{abstract}

Keywords: E-module, Kvisoft flipbook maker, Critical thinking skills.

\section{INTRODUCTION}

Critical thinking as a thought process to solve problems reflectively with logical, rational arguments, by collecting and interpreting information, and evaluating information to make decisions [1]. Critical thinking involves several steps consisting of identifying problems, thinking about goals, finding possible solutions, thinking about possible outcomes, trying one solution, and finally evaluating the results [2]. Students have the potential to develop thinking skills from the beginning so that they will grow into a critical thinker on a matter or state of decision-making [3]. So, the conclusion was process of critical thinking draws conclusions in puzzle out a problem that can help students acknowledge information.

The establishment of critical thinking skills supports students realize the information conveyed in learning [4]. Critical thinking skills became a major component in physics learning [5]. Physics has the aim of improving the ability of students in thinking systematic objective as well as creative [6]. Physics learning must have awareness, insight, depth, and ethics. Awareness of the importance of Physics will be supported if learning brings students to explore a considerable field in Physics [7]. If students are given the opportunity to use thought at a higher level at each grade level, they will eventually become accustomed to distinguishing between appearance and reality, facts and opinions, knowledge and beliefs [8]. Thus, this mental process will give a gradual rise to the critical thinking skills of students to study physics in-depth.

The critical thinking component of physics learning in high school often contains hypothetical concepts. Hypothetical concepts bring on problems in understanding by learners so need high preoccupation. 
The complicatedness of teaching was students lost interest in reading textbooks as well as physics books. Students lean to be inquiring in reading illustration books [9]. Physics is more enjoyable when presented in pictorial form, mostly in visualizing hypothetical concepts [10]. So, it takes an effective teaching material to help improve critical thinking skills.

The learning materials is grouped by shape and how it works. Teaching materials in the form of incuse teaching materials, listening materials, and hearing teaching materials. Corresponding to the development of the age of teaching materials not only in the form of books, but also can also be taken from the internet or from other sources in the form of journals, articles, electronic books (e-books), and electronic modules (emodules). Teaching materials using print media such as less effective modules are less attractive [11], so using e-modules makes it easier for students to access various materials to be studied [12]. One of the effective teaching materials is the e-module [13].

E-modules make students more independent in learning and learning and more focused on students. The learning process with e-modules makes students no longer dependent on teachers as the only source of information [14]. E-modules are useful electronicbased modules to convey information contained in the format of a hard disk, Compact Disk (CD), .apk, exe, or web to assist students in self-learning [15]. Emodules combine from print media and computers, so electronic modules can available information in a structured, attractive way and have a high level of interactivity [16].

Interactive related to the communication process of the communication section. The communication section in interactive multimedia is the relation between human beings as users and computers as a tool that provides information. Multimedia-based learning media creation is done using open-source software. The software is kvisoft flipbook maker (KFM) which is software that makes teaching materials into an electronic book display in the form of a flipbook [14].

KFM is a reliable software that can convert PDF files into digital publications. KFM can also change the appearance of a PDF to be attractive like a book [17]. The use of this software is not only text, images, video, and audio which can also be included so that the media display is more varied and the learning process becomes attractive [18].

Other research shows that the Physic e-modules effective for improving the critical thinking skills of learners in the learning process [13]. In addition, the use of KFM-assisted e-modules is able to make students better understand or delve into the material [19]. KFM application-assisted e-modules also get positive assessments because learning materials become very easy to understand by students [14]. After the development of e-module products the level of critical thinking of students increased [20]. Agree also with the results of other studies that show that the average value of critical thinking skills of students after using e-modules in learning is better than before using e-modules, so that e-modules are effective for improving the critical thinking skills of learners [21].

In this paper, it will be discussed the issue of developing KFM-based Physics e-module as a tool in the learning activity to build on critical thinking skills of students. Developing a Physics e-module that can be learned anywhere and anytime is supposed to ease the learning of students.

\section{RESEARCH METHOD}

This study was included in the development research. This development uses 4-D models (Define, Design, Develop, and Disseminate) which include the defining, planning, development, and deployment stages [22]. The research produced KFM-based Physics e-module products in exe format.

\subsection{Studies of Place and Time}

The study was conducted in May 2020 at Senior High School of 1 PAKEM, Yogyakarta. The research was conducted in the second semester of the 2019/2020 academic year.

\subsection{Studies Subject}

The subjects of the study were students of the tenth-grade of SMAN 1 PAKEM. The subject of the field trial was the tenth-grade student of Mathematics and Science 1 which numbered 34 students as the experiment class. Sample were taken using purposive sampling.

\subsection{Studies Procedure}

The research phases that had been conducted in this study included the analysis stage (analysis of the needs of learners based on the characteristics of learners, interpretation of the subject matter and curriculum), design (design of materials, arrange the creation of e-modules, and the collection of materials involved in the development of e-modules), development, implementation (implementation of emodules using KFM application), and the 
dissemination of product results to schools. The data in this study was obtained using e-module assessment sheets and test instruments. The research instruments used in this study are a test of critical thinking skills.

\subsection{Analysing Data}

Data obtained through research instruments is analyzed using SPSS. Analysis with SPSS is necessary to ensure that distributed data is normal and homogeneous. Descriptive data obtained from the validator. Once the instrument is evaluated by the expert, the assessment results are organized and calculated by $\mathrm{V}^{\prime}$ Aiken formula to find out the results of the validity of content with the following formula.

$\mathrm{V}=\frac{\sum \mathrm{s}}{[\mathrm{n}(\mathrm{c}-1)]}$

$\mathrm{s}$ was $\mathrm{r}-\mathrm{l}_{0}$ where $\mathrm{l}_{0}$ was the lowest validity assessment number, $\mathrm{c}$ was the highest validity rating number, $r$ was the number given by the validator. The score obtained from the validation of the KFM-based Physics e-module and the test question is then altered to a qualitative format with 4 criteria as stated by to the $\mathrm{V}^{\prime}$ Aiken interval index in Table 1 [23].

Table 1. Validation criteria

\begin{tabular}{|l|l|}
\hline Validity Result Styles & Validity Criteria \\
\hline $0.8<\mathrm{V} \leq 1$ & Very Adequate \\
\hline $0.6<\mathrm{V} \leq 0.8$ & Adequate \\
\hline $0.4<\mathrm{V} \leq 0.6$ & Less Adequate \\
\hline $0.2<\mathrm{V} \leq 0.4$ & Inadequate \\
\hline
\end{tabular}

The KFM-based Physics e-module assessment is examined by determine the mean score acquire from media experts and materials experts. The mean score of each component is determine using the formula:

$\overline{\mathrm{x}}=\frac{\sum \mathrm{x}}{\mathrm{n}}$

Where $\overline{\mathrm{x}}$ is the average score for each guideline, $\mathrm{n}$ is the number of assessors, and $\Sigma \mathrm{x}$ is the total score of each guideline. The results of learning devices and the responses of students are descriptive. The data result in the scale form converted into quantitative form. After acquire quantitative data, the data be treated in the form of a real score which states the validity value of the product that has been validated.

The classification is based on the proportion of the average ideal score $\left(\mathrm{X}_{\mathrm{i}}\right)$ and the ideal standard deviation score $\mathrm{SB}_{\mathrm{i}}$ ). The qualification levels are divided into five categories with the following criteria shown in Table 2.
Table 2. Assessment criteria of physics e-module based on KFM

\begin{tabular}{|c|c|}
\hline Score & $\overline{\text { Criteria }}$ \\
\hline $\mathrm{X} \geq \bar{X}_{i}+1.8 \mathrm{SB}_{\mathrm{i}}$ & Very Good \\
\hline$\overline{\mathrm{X}} \mathrm{i}+0.6 \mathrm{SB}_{\mathrm{i}}<\overline{\mathrm{X}} \leq \overline{\mathrm{X}} \mathrm{i}+1.8 \mathrm{SB}_{\mathrm{i}}$ & Good \\
\hline$\overline{\mathrm{X}} i-0.6 \mathrm{SB}_{\mathrm{i}}<\overline{\mathrm{X}} \leq \overline{\mathrm{X}} \mathrm{i}+0.6 \mathrm{SB}_{\mathrm{i}}$ & Good Enough \\
\hline $\bar{X}_{i-1.8 ~ S B}<\bar{X} \leq \bar{X}_{i-0}-6 S_{i}$ & Less Good \\
\hline $\bar{X} \leq \bar{X}_{i-1,8 S B_{i}}$ & Very Less Good \\
\hline
\end{tabular}

$\overline{\mathrm{X}}$ is the actual score, $\overline{\mathrm{X}} \mathrm{i}$ is the average ideal which $\frac{1}{2}$ (ideal maximum score + ideal minimum score), and $\mathrm{SB}_{\mathrm{i}}$ is the ideal standard deviation which $\frac{1}{6}$ (ideal maximum score- ideal minimum score). The form of this research is a pre-experimental design with one group of pretest and posttest design as shown in Figure 1.

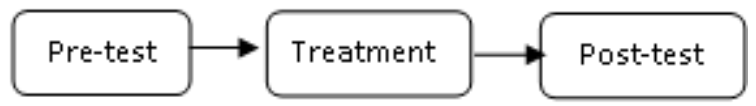

Figure 1 One group pretest-posttest

Treatment is given to the class using KFM-based Physics e-modules. The e-modules developed are applied to the experiment class. Data obtained from the pre-test and post-tests are analyzed descriptively and quantitatively. Each improvement in learning achieved by the learners is determined by calculating the scoring of the test results of each student.

Data analysis using quantitative and qualitative analysis techniques. Pre-test and post-test data generated from the experiment class are analyzed with descriptive statistics and sign test using the SPSS application. The $\mathrm{N}$-Gain test was also conducted to see a large improvement in the critical thinking skills of learners, using the following formula [24]. The category of acquisition of N-Gain can be seen in Table 3.

$$
\mathrm{N}-\text { Gain }=\frac{\mathrm{s}_{\text {posttest }}-\mathrm{s}_{\text {pretest }}}{\mathrm{s}_{\text {max }}-\mathrm{s}_{\text {pretest }}} \times 100 \%
$$

Table 3. N-gain level criteria

\begin{tabular}{|l|l|}
\hline Interval & Criteria \\
\hline $\mathrm{g}>70$ & High \\
\hline $30 \leq \mathrm{g} \leq 70$ & Medium \\
\hline $\mathrm{g}<30$ & Low \\
\hline
\end{tabular}

\section{RESULTS AND DISCUSSION}

The results of this paper are physics teaching and material integrated with KFM-based e-modules. E- 
modules developed for harmonic motion material on spring vibrations. The development of e-modules aims to enhance critical thinking skills and help teachers facilitate the learning of students anywhere and anytime. This stage of research is limited by product validation. A product that is valid and feasible to use under the validator's assessment. Validators are conducted by media expert lecturers, material expert lecturers, and field practitioners. $V^{\prime}$ Aiken calculation stipulates that the KFM-based Physics e-module developed and the research instrument are valid. Both validation levels fall into the high classification presented in Table 4.

Table 4. Results of data collection instrument validity

\begin{tabular}{|l|l|l|l|}
\hline No & $\begin{array}{l}\text { Data Collection } \\
\text { Instrument }\end{array}$ & $\begin{array}{l}\text { V'Aiken } \\
\text { Coefficient }\end{array}$ & Explanation \\
\hline 1 & $\begin{array}{l}\text { Assessment of } \\
\text { learning instrument }\end{array}$ & 1 & $\begin{array}{l}\text { Valid (Very } \\
\text { Adequate) }\end{array}$ \\
\hline 2 & $\begin{array}{l}\text { Task assessment } \\
\text { sheet }\end{array}$ & 1 & $\begin{array}{l}\text { Valid (Very } \\
\text { Adequate) }\end{array}$ \\
\hline
\end{tabular}

The results of the assessment of KFM-based Physics e-modules by validators are shown in Table 5 . Table 5 represents that the average score of media assessments by validators is 2.89 with excellent categories.

The assessment results show that e-modules are worth implementing in learning. An e-module display of KFM-based Physics developed on harmonic motion material on spring vibrations is shown in Figure 2 and 3.

Table 5. Results of e-module physics based on KFM assessment

\begin{tabular}{|l|l|l|}
\hline Aspect & $\begin{array}{l}\text { Assessment } \\
\text { Result }\end{array}$ & Explanation \\
\hline Media Expert & & Very Good \\
\hline - Navigation & 2.84 & Very Good \\
\hline $\begin{array}{c}\text { - Learning media } \\
\text { display }\end{array}$ & 2.88 & Very Good \\
\hline Material Expert & & Very Good \\
\hline $\begin{array}{c}\text { - Learning } \\
\text { competency }\end{array}$ & 2.96 & Very Good \\
\hline - Material & 2.92 & Very Good \\
\hline - Task & 2.85 & Very Good \\
\hline Average score & 2.89 & Very Good \\
\hline
\end{tabular}

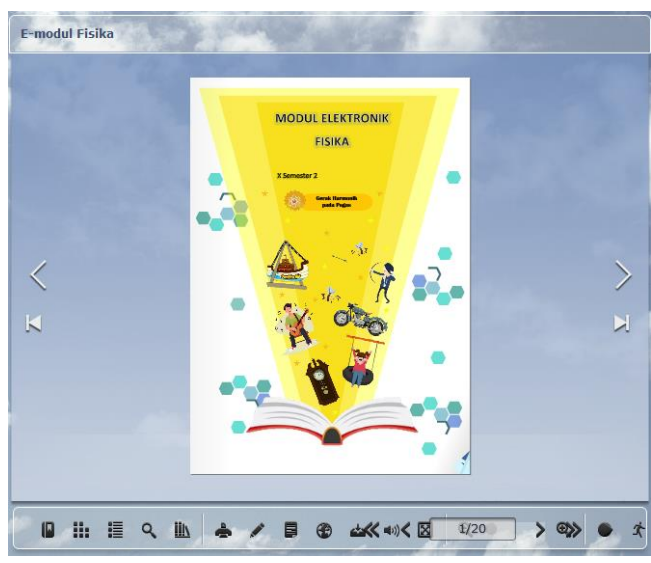

Figure 2 Cover of the KFM-based physics e-module

The first display of the e-module is designed to make it easier for students to learn. Starting from the title of the learned material, concept map, learning competency, material, spring animated image, training question, and application of concepts in daily life. The e-module was examined on students as a thru in build on the critical thinking skills [25].

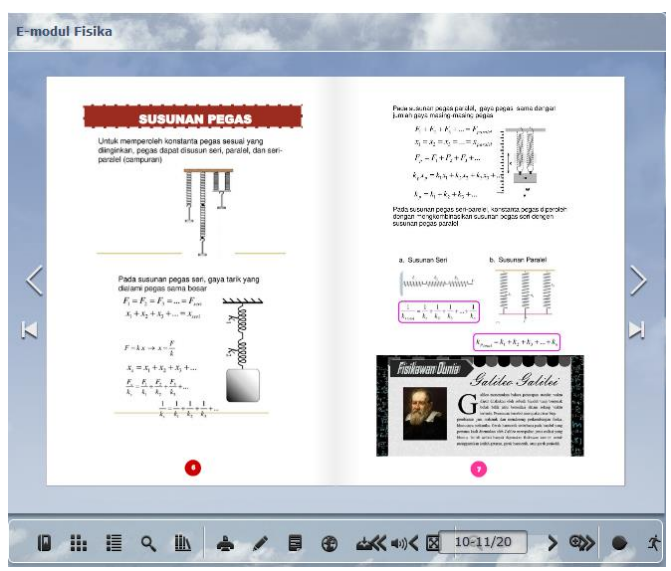

Figure 3 Content of the KFM-based physics emodule material

Statistical data results of the critical thinking skills of students thru the conclusion of pretest and posttest scores to discover the mean before and after treatment. The instruments used in the pretest and posttest must be valid instruments [26]. The SPSS calculation is found in Table 6. In the development test of e-module Physics-based KFM think critical students measured through pretest and posttest activities conducted at the beginning and the end of the meeting. Data measuring the critical thinking skills of the students obtained aims to test the effectiveness of the e-module Physics-based KFM on harmonic motion material in spring vibrations. Measurement results data are analyzed using descriptive statistics. The results of the analysis are shown in Table 6. 
Table 6. Results of descriptive statistical analysis

\begin{tabular}{|c|c|c|c|}
\hline & Pretest & Post-test & $\begin{array}{c}\text { Valid N } \\
\text { (list-wise) }\end{array}$ \\
\hline $\mathrm{N}$ & 34 & 34 & 34 \\
\hline Minimum & 56 & 64 & \\
\hline Maximum & 78 & 98 & \\
\hline Mean & 62.21 & 83.62 & \\
\hline Std. Dev & 6.687 & 8.627 & \\
\hline
\end{tabular}

The rate post-test score of the learner is higher than the average pre-test score indicating an increase. Thus, it can be culminated that there is distinction in critical thinking skills before and after learning with the innovations implemented. Next, the data is analyzed using the sign test. The first sign test output result is the frequency that can be seen in Table 7 .

Table 7. Sign test frequency

\begin{tabular}{|l|l|l|}
\hline \multirow{4}{*}{$\begin{array}{l}\text { Post-test- } \\
\text { Pre-test }\end{array}$} & Negative Differences $^{\text {a }}$ & $\mathbf{N}$ \\
\cline { 2 - 3 } & Positive Differences $^{\text {b }}$ & 34 \\
\cline { 2 - 3 } & Ties $^{c}$ & 0 \\
\cline { 2 - 3 } & Total & 34 \\
\hline
\end{tabular}

a. Posttest $<$ Pretest, b. Posttest $>$ Pretest, c. Posttest $=$ Pretest

Table 7 shows that the overall critical thinking skills of students expand judging by posttest scores higher than pretest scores. The output results from the analysis of sign test data are presented in Table 8.

Table 8. Analysis results of sign test

\begin{tabular}{|l|l|}
\hline & Posttest - Pretest \\
\hline$Z$ & $-5.659^{\text {a }}$ \\
\hline Asymp. Sig. (2-tailed) & 0.000 \\
\hline
\end{tabular}

a. Sign Test

The result of the analysis sign test in Table 8 using a level of significance $(\alpha)$ of $5 \%$, it can be deduced that the rejected zero hypotheses designated by the value of sig. $=0.00<0.05(\alpha)$, then the e-module of KFMbased physics developed can build on the critical thinking skills of learners. Students' critical thinking skills are trained from some of the enrichment contained in the e-module. The enrichment provided is in accordance with indicators of critical thinking, such as analysing arguments, making observations and assessing reports, deducing and considering deductions, defining terms and considering definitions, and deciding on an action.

Students are supposed to be able to identify the relationship between mass and period produced by the spring according to the concept of simple harmonic motion appropriately. In addition, students can analyze the period, frequency, and length increase of the spring circuit. The developed e-module provides illustrations related to harmonic motion on spring vibrations. Then, also presented illustrations along with examples of spring vibrations in everyday life, so as to upgrade students' critical thinking skills. Students' critical thinking skills that improve after being treated using an e-module can be counted by determined a normalized N-Gain formula that shown in Figure 4.

Figure 4 represents an increase in the value of critical thinking skills of Mathematics and Science of the tenth-grade $1 \mathrm{X}$-grade students after using the KFM-based Physics e-module. Based on Figure 3, there appears to be a link between critical thinking skills and the KFM-based Physics e-module developed. This is because students can access emodules anywhere and anytime. Packaged e-modules are interactive involving audio visual displays, sounds, animations, and so on. In its use, it is easy to acknowledge so that it can be used as a better learning medium [16]

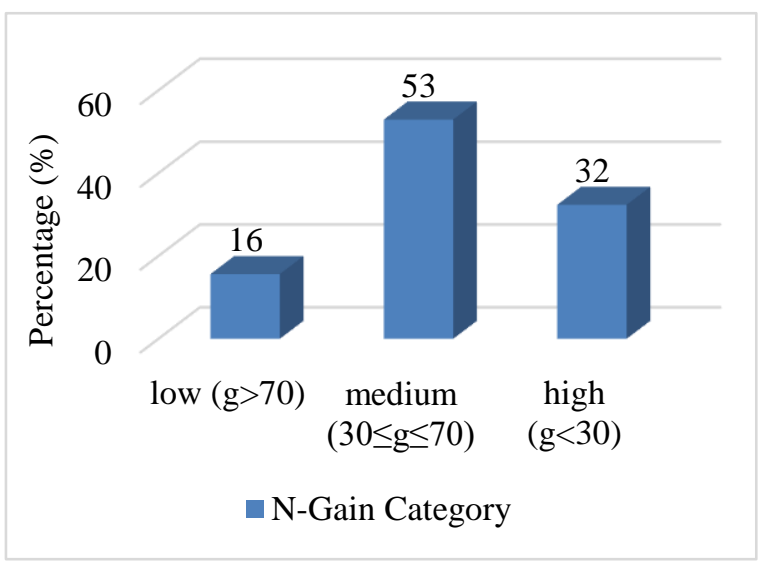

Figure 4 The improvement of critical thinking skill using N-gain

The introduction and guidance of KFM-based Physics e-modules should be taken into account so that at the time of learning activities students do not have difficulty in using them so that the improvement of students' critical thinking skills can develop optimally. Besides, the development of KFM-based Physics emodules needs to be applied to different materials to know the level of effectiveness.

\section{CONCLUSION}

KFM-based Physics e-modules developed fall into the valid category and are feasible for use based on expert assessments of media and valid materials. The 
learning used by KFM-based Physics e-modules, especially in harmonic motion materials in spring vibrations, was able to build on the critical thinking skills of students. The impact of the KFM-based Physics e-module with critical thinking skills is showed by statistical test results using the sign test.

\section{REFERENCES}

[1] Zainudin, B. Pambudi, Development Critical Thinking Skill-Based Learning Set of Basic Physics Subject Using Edmodo in Android Platform Jurnal Pendidikan Fisika Indonesia 15(1) (2019) 14-23. DOI: https://doi.org/10.15294/jpfi.v15i1.14350

[2] K. Changwong, A. Sukkamart, B. Sisan, Critical Thinking Skill Development: Analysis of A New Learning Management Model for Thai High Schools Journal of International Studies, 11(2) (2018) 37-48. DOI: https://doi.org/10.14254/2071-8330.2018/11-2/3

[3] D. Naomi, Z. Prasetyo, Pengembangan Instrumen Penilaian IPA untuk Memetakan Critical Thinking dan Practical Skill Peserta Didik SMP, Jurnal Inovasi Pendidikan IPA 2(2) (2016) 213222.

DOI:

https://dx.doi.org/10.21831/jipi.v2i2.11963

[4] F. Demirci, C. Özyürek, The Effect of Using Concept Cartoons in Astronomy Subjects on Critical Thinking Skills Among Seventh Grade Student, International Electron Journal of Elementary Education 10(2) (2017) 243-254. DOI: https://doi.org/10.26822/iejee.2017236119

[5] N. Sholihah, I Wilujeng, S. Purwanti, Development of android-based learning media on light reflection material to improve the critical thinking skill of high school students, in: Journal of Physics: Conference Series, vol. 1440, IOP Publishing, Bristol, 2020, pp. 1-6. DOI: https://doi.org/10.1088/1742$\underline{6596 / 1440 / 1 / 012034}$

[6] R.S. Damayanti, A. Suyatna, Warsono, U. Rosidin, Development of authetic assessment instrumen for critical thinking skills in global warming with a scientific approach, in: International Journal of Science and Applied Science: Conference Series, vol. 2, Universitas Sebelas Maret, Surakarta, 2017, pp. 289-299. DOI: https://doi.org/10.20961/ijsascs.v2i1.16730
[7] A. Rusli, Pendidikan Fisika untuk Abad Ke 21: Kesadaran, Wawasan, Kedalaman, Etika, Jurnal Fisika Indonesia 17(50) (2013) 16-19. DOI: https://doi.org/10.22146/jfi.24417

[8] I. Kurniawati, Wartono, M. Diantoro, Pengaruh Pembelajaran Inkuiri Terbimbing Integrasi Peer Instruction terhadap Penguasaan Konsep dan Kemampuan Berpikir Kritis Siswa, Jurnal Pendidikan Fisika Indonesia 10(1) (2014) 36-46. DOI: https://doi.org/10.15294/jpfi.v10i1.3049

[9] D.P. Handayani, Jumadi, I. Wilujeng, H. Kuswanto, Development of comic integrated student worksheet to improve critical thinking ability in microscope material, Journal of Physics: Conference Series, vol. 1233, IOP Publishing, Bristol, 2019, pp. 1-8. DOI: https://doi.org/10.1088/17426596/1233/1/012069

[10] M. Abbas, Penerapan Animasi Macromedia Flash untuk Meningkatkan Hasil Belajar Fisika pada Materi Tekanan, Ed-Humanistics 04(1) (2019) 509-517. DOI: https://doi.org/10.33752/edhumanistics.v4i1.359

[11] N.S. Herawati, A. Muhtadi, Pengembangan Modul Elektronik (E-Modul) Interaktif pada Mata Pelajaran Kimia Kelas XI SMA, Jurnal Inovasi Teknologi Pendidikan 5(2) (2018) 180191.

DOI: https://doi.org/10.21831/jitp.v5i2.15424

[12] Sarwandi, M. Giatman, Sukardi, D. Irfan, Developing Mobile-Based Project-Based Learning Module for Project Management Courses in Vocational Education Jurnal Pendidikan Vokasi 9(2) (2019) 207-216. DOI: https://doi.org/10.21831/jpv.v9i2.25947

[13] F. Perdana, Sarwanto, Sukarmin, Sujadi, Development of e-module combining science process skills and dynamics motion material to increasing critical thinking skills and improve student learning motivation senior high school, in: International Journal of Science and Applied Science: Conference Series, vol. 1, Universitas Sebelas Maret, Surakarta, 2017, pp. 45-54. DOI: https://doi.org/10.20961/ijsascs.v1i1.5112

[14] D. Sugianto, A. Abdullah, S. Elvyanti, Y. Muladi, Modul Virtual: Multimedia Flipbook Dasar Teknik Digital, Jurnal Invotec 9(2) (2013) 110116.

DOI: 
[15] I. Permana, I. Wirawan, I. Sindu, Pengembangan E-Modul Berbasis Project Based Learning pada Mata Pelajaran Pemrograman Berorientasi Objek Kelas XI RPL SMK Negeri 2 Tabanan, Jurnal Nasional Pendidikan Teknik Informatika 6(2) (2017) 140-154. DOI: https://dx.doi.org/10.23887/janapati.v6i2.11083

[16] W. Suwatra, A. Suyatna, U. Rosidin, Development of Interactive E-Module for Global Warming to Grow of Critical Thinking Skills, International Journal of Advanced Engineering, Management and Science 4(7) (2018) 543-549. DOI: https://dx.doi.org/10.22161/ijaems.4.7.7

[17] N. Mulyaningsih, D. Saraswati, Penerapan Media Pembelajaran Digital Book dengan Kvisoft Flipbook Maker, Jurnal Pendidikan Fisika 5(1) (2017) $25-32$.

DOI: https://dx.doi.org/10.24127/jpf.v5i1.741

[18] I. Sanuaka, K. Ariawan, I. Sutaya, Pengembangan Media Pembelajaran Electronic Book (E-Book) Interaktif Multimedia dalam Mata Pelajaran Teknik Animasi 3D dan Teknik Animasi 2D di Jurusan Multimedia SMK Negeri 3 Singaraja, Jurnal Pendidikan Teknik Elektro Undiksha 6(1) (2017) 9-20. DOI: https://dx.doi.org/10.23887/jipte.v6i1.20226

[19] H. Nufus, Susilawati, R. Linda, Implementation of E-Module Stoiciometry Based on Kvisoft Flipbook Maker for Increasing Understanding Study Learning Concepts of Class X Senior High School, Journal of Educational Sciences 4(2) (2020) 261-272. DOI: https://dx.doi.org/10.31258/jes.4.2.p.261-272

[20] P. Nikita, A. Leksmono, A. Harijanto, Pengembangan E-Modul Materi Fluida Dinamis untuk Meningkatkan Kemampuan Berpikir Kritis Siswa SMA Kelas XI, Jurnal Pembelajaran Fisika vol. 7(2) (2018) 175-180. DOI: https://doi.org/10.19184/jpf.v7i2.7925

[21] R. Sujanem, I. Suwindra, I. Suswandi, The effectiveness of problem-based interactive physics e-module on high school students' critical thinking, in: Journal of Physics: Conference Series, vol. 1503, IOP Publishing, Bristol, 2018, pp. 1-10. DOI: https://doi.org/10.1088/17426596/1503/1/012025

[22] Zainuddin, A.R. Hasanah, M.A. Salam, Misbah, S. Mahtari, Developing the interactive multimedia in physics learning, in: Journal of
Physics: Conference Series, vol. 1171, IOP Publishing, Bristol, 2019, pp. 1-5. DOI: https://doi.org/10.1088/17426596/1171/1/012019

[23] C. Zarkasyi, C. Partana, Profile of students' selfefficacy in chemistry learning: case study at senior high school, in: Journal of Physics: Conference Series, vol. 1440, IOP Publishing, Bristol, 2020, pp. 1-6. DOI: https://doi.org/10.1088/17426596/1440/1/012011

[24] N. Fitriani, Gunawan, Sutrio, Berpikir Kreatif dalam Fisika dengan Pembelajaran Conceptual Understanding Procedures (CUPs) Berbantuan LKPD, Jurnal Pendidikan Fisika dan Teknologi 3(1) (2017) 24-33. DOI: https://dx.doi.org/10.29303/jpft.v3i1.319

[25] M. Saputra, H. Kuswanto, The Effectiveness of Physics Mobile Learning (PML) with Hombobatu Theme to Improve The Ability of Diagram Representation and Critical Thinking Of Senior High School Students, International Journal of Instruction 12(2) (2019) 471-490. DOI: https://doi.org/10.29333/iji.2019.12230a

[26] M.A Ihwan, S.S. Sari, M.S. Ali, Pengembangan Instrumen Tes Hasil Belajar Kognitif Fisika Kelas XI MIA SMA Negeri 5 Pinrang, Jurnal Sains dan Pendidikan Fisika 15(2) (2019) 50-57. DOI: https://doi.org/10.35580/jspf.v15i2.11036 